\title{
Analisis Aliran Fluida Udara akibat Pendaratan Helikopter terhadap Permukaan Helideck pada Kapal
}

\author{
M. Zain Fajar Ramadhani dan I Ketut Aria Pria Utama \\ Jurusan Teknik Perkapalan, Fakultas Teknologi Kelautan, Institut Teknologi Sepuluh Nopember (ITS) \\ e-mail: zainf9@gmail.com
}

\begin{abstract}
Abstrak-Heliport adalah suatu lapangan terbang atau suatu daerah tertentu di darat atau di perairan atau di suatu struktur, terdiri dari bangunan atau fasilitas (peralatan) yang dipakai sebagian atau seluruhnya untuk melakukan pendaratan, keberangkatan dan pergerakan pesawat helikopter. Helideck adalah tempat pendaratan dan lepas landas helikopter di perairan. CFD (Computational Fluid Dynamics) merupakan "pendekatan ketiga" dalam studi dan pengembangan di bidang dinamika fluida secara keseluruhan selain pendekatan teori dan eksperimen murni. Dari prinsip kekekalan energi, berkerjanya baling-baling adalah sama terhadap banyak energi yang diperoleh dari fluida per unit waktu. Bekerja per unit waktu, atau jumlah power yang dikonsumsi oleh baling-baling. Kecepatan 45 mph adalah kecepatan yang menyebabkan manusia akan terhempas. Kecepatan $\mathbf{4 5} \mathrm{mph}$ tersebut memasuki kriteria angina kencang sekali. Adapun metode yang digunakan : Studi Literatur dan pencarian data, pembuatan model, meshing dan CFX, Validasi, penyajian. Kecepatan rata-rata angin tertinggi dihasilkan dari pendaratan helikopter sebesar $19,614 \mathrm{~m} / \mathrm{s}$. Kecepatan angin terendah dihasilkan dari pendaratan helikopter sebesar 7,142 m/s. Secara umum hembusan angin yang dihasilkan dari pendaratan helikopter aman bagi kru yang bekerja di helideck.
\end{abstract}

Kata Kunci-Helideck, kecepatan angin, helikopter, CFD.

\section{PENDAHULUAN}

$\mathrm{M}$ ENURUT [1] pengertian pesawat udara tentang penerbangan adalah setiap mesin atau alat yang dapat terbang di atmosfer karena gaya angkat dari reaksi udara, tetapi bukan karena reaksi udara terhadap permukaan bumi yang digunakan untuk penerbangan Indonesia. Selain itu pesawat udara dalam Undang-undang Penerbangan juga dikenal dengan istilah pesawat terbang dan helikopter.

Helideck adalah tempat pendaratan dan lepas landas helikopter di perairan. Sedang Heliport adalah suatu lapangan terbang atau suatu daerah tertentu di darat atau di perairan atau di suatu struktur, terdiri dari bangunan atau fasilitas (peralatan) yang dipakai sebagian atau seluruhnya untuk melakukan pendaratan, keberangkatan dan pergerakan pesawat helikopter [2]. Dalam peratura tersebut, juga menjelaskan bahwa pentingnya persyaratan keselamatan dalam Heliport. Melihat pentingnya keselamatan, tidak heran apabila perizinan pembuatan heliport begitu ketat. Apabila ada pihak pengguna/pembuat heliport tidak dapat memenuhi ketentuan persyaratan keselamatan, maka izin operasi akan dicabut.

CFD (Computational Fluid Dynamics) merupakan "pendekatan ketiga" dalam studi dan pengembangan di bidang dinamika fluida secara keseluruhan selain pendekatan teori dan eksperimen murni. Dengan hadirnya komputer digital berkecepatan tinggi dan dikombinnasikan dengan pengembangan dari ketelitian algoritma numerik untuk penyelesaian masalah fisik pada komputer maka telah merubah dengan cepat cara kita dalam belajar dinamika fluida [3].

Pada penelitian [4] mengenai aliran fluida di atas deck kapal saat pendaratan helikopter. Adapun variabelnya dengan ketinggian hembusan $1,5 \mathrm{~m}, 3,5 \mathrm{~m}$, dan $5,5 \mathrm{~m}$. Pemodelan yang dipergunakan dengan penggambaran angin dihembuskan pada jarak ketinggian variabel terhadap pelat datar, input yang dipergunakan bilangan Reynold. Luaran yang dapat diperoleh adalah kecepatan udara hembusan dan radius jangkauan hembusan angin.

Penelitian ini mengambil keunggulan penggunaan kelebihan CFD saat ini dibandingkan dengan yang dilaporkan oleh [4]. Secara fungsi CFD sekarang lebih banyak kelebihannya, pengkondisian inlet yang lebih lengkap dan pemodelan yang lebih mudah. Perbedaan yang dapat dikoreksi dari laporan [4] meliputi pendekatan model dengan mengikuti kondisi lapangan, koreksi variabel ketinggian, dan penyempurnaan pemodelan (inlet) hembusan angin dari baling-baling.

\section{TINJAUAN PUSTAKA}

\section{A. $C F D$}

Computational fluid dynamics, biasanya disingkat sebagai $\mathrm{CFD}$, adalah cabang dari mekanika fluida yang menggunakan metode numerik dan algoritma untuk memecahkan dan menganalisis masalah yang melibatkan aliran fluida. Komputer digunakan untuk melakukan perhitungan yang diperlukan untuk mensimulasikan interaksi antara zat cair dan gas dengan permukaan yang didefinisikan oleh kondisi batas [3].

Ada tiga manfaat umum CFD yang dikenal secara luas, yaitu insight, foresight dan efficiency [5].

\section{B. Persamaan Kecepatan Thrust}

Dalam konsep, akan diasumsikan bahwa udara melewati baling-baling satu dimensi, seolah-olah stabil, tidak tertahan dan mengalir. Menurut fluida ideal bahwa ketika satu fluida mengalir maka tidak ada gesekan antar elemen fluida tersebut. Oleh karena itu gagal induksi merupakan satu satunya kerugian dalam fluida dengan kerugian lain yang dihasilan dari aksi viskositas yang diasumsikan tidak berubah sepanjang waktu. 
Sehingga diasumsikan bahwa alirannya satu dimensi dan sifatnya konstan antar baling-baling saat dilewati yang artinya sifat fluida berubah saat posisiya relatif vertikal terhadap baling-baling.

Dalam kasus mengambang di udara kontrol voume udara disekitar baling-baling dan bergelombang diarea permukaan $\mathrm{S}$ yang ditunjukan pada Gambar 1 [6] Dengan dS unit normal.

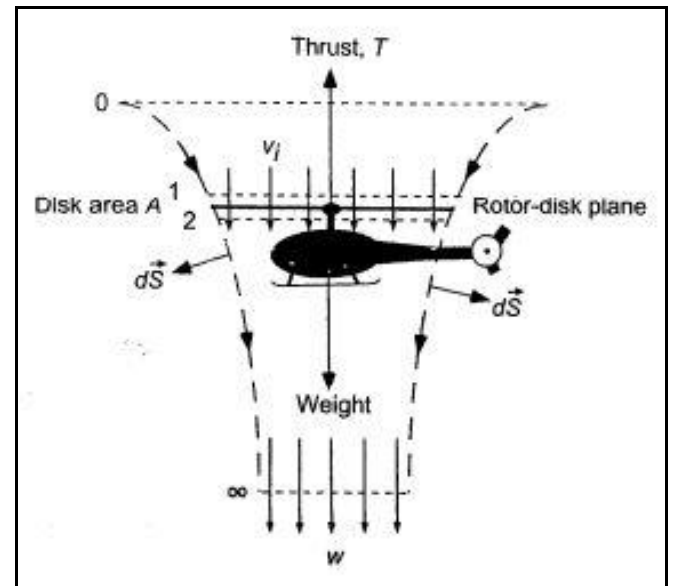

Gambar 1. Model Aliran Analisa Teori Momentum pada rotor saat terbang melayang

Area vektor yang mana biasanya selalu menujukkan volume kontrol menyebrang permukaan S. Persamaan umum yang mengatur penerapan konservasi dari masa fluida terhadap kontrol volume dapat dituliskan sebagai berikut.

$$
\iint_{g} \rho \vec{V} \cdot d \vec{S}=0
$$

Dimana $\mathrm{V}$ adalah kecepatan lokal dan $\rho$ adalah masa jenis dari fluida. Persamaan ini menunjukan bahwa aliran massa yang masuk volume kontrol harus sama dengan aliran masa keluar dari volume kontrol. Perhatikan bahwa ini merupakan persamaan skalar. Kesamaannya, persamaan yang mengatur konservasi dari momentum fluida dapat dituliskan sebagai berikut.

$$
\vec{F}=\iint_{g} p d \vec{S}+\iint_{g}(\rho \vec{V} \cdot d \vec{S}) \vec{V}
$$

Untuk aliran yang terus mengalir, gaya tekanan total fluida di dalam kontrol volume sama dengan nol. Oleh karena itu gaya total ada fluida $\mathrm{F}$, adalah sejalan dengan laju perubahan momentum fluida terhadap waktu saat menyebrang permukaan S. Meskipun (2) adalah berupa persamaan vektor, ini dapat disederhanakan dengan asumsi seolah-olah aliran satu dimensi. Pada dasarnya pengenyampingan dari asumsi tekanan sama melompati luasan baling-baling dan menyebabkan distribusi yang sama pada kecepatan sepanjang horisontal saat menyebrang di bawah volume kontrol. Karena gaya pada fluida disuplai oleh baling-baling berdasarkan hukum newton III fluida yang mendesak harus sama dengan gaya pada seberang baling-baling. Gaya ini adalah daya dorong rotor, T. Sehingga persamaan umum yang mengatur energi konservasi pada aliran dapat dituliskan sebagai berikut.

$$
W=\iint_{g} \frac{1}{2}(\rho \vec{V} \cdot d \vec{S})|\vec{V}|^{2}
$$

Persamaan ini secara sederhana berguna pada fluida dengan menunjukkan baling-baling memperoleh energi kinetik dari fluida dalam perwujudan unit waktu. Ini juga merupakan persamaan skalar.

Berdasarkan asumsi bahwa aliran seolah-olah konstan dan prinsip dari konservasi masa, laju aliran massa, $\mathrm{m}$ harus bersifat konstan dalam garis batas baling-baling rotor. Oleh karena itu laju aliran massa adalah

$$
\dot{m}=\iint_{s} \rho \vec{V} \cdot d \vec{S}=\iint_{2} \rho \vec{V} \cdot d \vec{S}
$$

Dan 1-D asumsi aliran tidak tertahan mengurangi persamaan ini menjadi

$$
\dot{m}=\rho A_{m s} w=\rho A_{2} v_{i}=\rho A v_{i}
$$

Prinsip kekekalan momentum fluida memberikan hubungan antara thrust baling-baling, $\mathrm{T}$, dan waktu laju perubahan total dari momentum fluida keluar dari volume kontrol (Hukum Newton II). Thrust baling-baling sama dan berbanding terbalik terhadap gaya fluida. Dimana ditunjukan dengan

$$
-\vec{F}=T=\iint_{m=0} \rho(\vec{V} \cdot d \vec{S}) \vec{V}-\iint_{0} \rho(\vec{V} \cdot d \vec{S}) \vec{V}
$$

Karena dalam melayang penerbangan kecepatan baik hulu rotor adalah diam, istilah kedua di sisi kanan negatif persamaan di atas adalah nol. Oleh karena itu, untuk masalah di ambang atas, dorong rotor dapat ditulis sebagai persamaan skalar

$$
T=\iint_{m s} \rho(\vec{V} \cdot d \vec{S}) \vec{V}=\dot{m} w
$$

Dari prinsip kekekalan energi, berkerjanya baling-baling adalah sama terhadap banyak energi yang diperoleh dari fluida per unit waktu. Bekerja per unit waktu, atau jumlah power yang dikonsumsi oleh baling-baling, Tvi dan hasilnya ditunjukan oleh persamaan

$$
T v_{\mathrm{i}}=\iint_{s=} \frac{1}{2} \rho(\vec{V} \cdot d \vec{S}) \vec{V}^{2}-\iint_{0} \frac{1}{2} \rho(\vec{V} \cdot d \vec{S}) \vec{V}^{2}
$$

Pada Persamaan bagian kanan bernilai 0

$$
T v_{i}=\iint_{s=} \frac{1}{2} \rho(\vec{V} \cdot d \vec{S}) \vec{V}^{2}=\frac{1}{2} m^{2} w^{2}
$$

Dari (7) dan (9) jelas bahwa

$$
v_{i}=\frac{1}{2} w
$$

Atau $\mathrm{w}=2$ vi. Oleh karena itu diberikan hubungan sederhana antara kecepatan induksi pada rotor pesawat, vi dan kecepatan w dalam vena contracta.

Karena kecepatan aliran meningkat pada area di bawah baling-baling, pertimbnagan kontinuitas mensyaratkan bahwa area dari slipstream harus menurun. berdasarkan observasi dari masa fluida antara rotor dan vena contracta Atau $\mathrm{w}=2$ vi. Oleh karena itu diberikan hubungan sederhana antara kecepatan induksi pada rotor pesawat, vi dan kecepatan w dalam vena contracta.

$$
\rho A v_{\mathrm{i}}=\rho A_{\mathrm{ms}} w=\rho A_{\mathrm{se}}\left(2 v_{\mathrm{i}}\right)=2 \rho A_{\mathrm{ms}} v_{\mathrm{i}}
$$

Sehingga rasio ambang dari area persilangan secara keselurahan luasan terjauh batasan terhadap area luasan baling-baling

$$
\frac{A_{\mathrm{mo}}}{A}=\frac{1}{2}
$$


Tabel 1.

Dengan kata lain, berdasarkan asumsi fluida ideal, vena contracta adalah area yang tepat $1 / 2$ dari area luasan balingbaling. sebagai kemungkina lain, radius dari batas jauh luasan, $\mathrm{r} \infty$, sebanding dengan rotor, $\mathrm{R}$, dengan dapat ditunjukan sebagai berikut

$$
r_{\mathrm{se}}=\frac{R}{\sqrt{2}}
$$

Oleh karena itu, rasio dari radius baling-baling dengan radius motor adalah $1 / \sqrt{2}=0,707$. ini disebut dengan rasio kontraksi baling-baling. pada prakteknya, sudah ditemukan secara eksperimen bahwa rasio kontraksi baling-baling tidak sebesar nilai teoritisnya oleh teori momentum; sekitar 0,78 dibandingkan terhadap 0,707. Ini berarti konsekuensi dari vikositas fluida, kenyataannya pemasukan yang seragam akan menghasilkan disk (luasan lingkaran) dan kecepatan putaran angin yang kecil di dalam induksi baling-baling rotor oleh putaran baling-baling rotor. Biasanya secara langsung mengakibatkan viskositas dari fluida menjadi tidak ideal.

Sebelumnya sudah dijelaskan menggunakan (7) bahwa teori mementum dapat digunakan untuk menghubungkan thrust baling-baling dengan kecepatan induksi pada luasan balingbaling dengan menggunakan persamaan berikut

$$
T=\dot{m} w=\dot{m}\left(2 v_{i}\right)=2\left(\rho A v_{i}\right) v_{i}=2 \rho A v_{i}^{2}
$$

Disusun kembali persamaan ini dan mengatasi masalah kecepatan induksi pada luasan baling-baling

$$
v_{h} \equiv v_{i}=\sqrt{\frac{T}{2 \rho A}}=\sqrt{\left(\frac{T}{A}\right) \frac{1}{2 \rho}}
$$

Rasio T / A dikenal sebagai loading disk, yang merupakan parameter yang sangat penting dalam analisis helikopter. Perhatikan bahwa vh $\equiv$ vi digunakan untuk mewakili kecepatan diinduksi di ambang atas. Nilai ini akan digunakan kemudian sebagai referensi ketika lepas landas dan kondisi pendaratan [9].

\section{Kecepatan Angin terhadap Manusia}

Gaya yang dapat membuat kita tertahan di tanah adalah gaya gesek statis. Dirumuskan

$$
F_{g}=\mu m g
$$

Kekuatan yang melawan gaya tersebut adalah gaya tarik atau gaya dorong dari angin. Dalam bilangan kecepatan Reynaulds diformulasikan

$$
F_{d}=\frac{1}{2} \rho v C_{d} A
$$

Dimana $\rho$ adalah masa jenis udara, $\mathrm{v}$ adalah kecepatan angin, $\mathrm{Cd}$ adalah koefisien hambatan berdimensi, dan A adalah luas penampang tubuh yang terkena udara. Dari ke dua persamaan tersebut didapatkan rumus gabungan dari ke dua rumus:

$$
v^{2}=\frac{2 \mu m 9}{\rho C_{d} A}
$$

Nilai $\rho=1,2 \mathrm{~kg} / \mathrm{m} 3 . \mathrm{m}$ merupakan massa manusia, diambil nilai $60 \mathrm{~kg}$. g adalah percepatan grafitasi bumi bernilai 9,81 $\mathrm{m} / \mathrm{s}$. Nilai CdA diberikan $\approx 0,84$. Nilai $\mu=0,4$. Maka didapatkan nilai kecepatan angin yang dapat menggerakkan manusia saat diam $\approx 21,5 \mathrm{~m} / \mathrm{s}$ atau sekitar $45 \mathrm{mph}$.

Kecepatan $45 \mathrm{mph}$ adalah kecepatan yang menyebabkan manusi akan terhempas. Kecepatan 45 mph memasuki kriteria
Tabel Kategori Kecepatan Angin Beaufort

\begin{tabular}{lll}
\hline \hline No & $\begin{array}{l}\text { Katagori } \\
\text { Kecepatan }\end{array}$ & $\begin{array}{l}\text { Kecepatan Angin } \\
(\mathrm{m} / \mathrm{s}) \quad ; \mathrm{mph}\end{array}$ \\
\hline 1 & Tenang & $0-0,3(0-0,67)$ \\
2 & Sedikit Tenang & $0,3-1,5(0,67-3,36)$ \\
3 & Sedikit Hembusan & $1,5-3,3(3,36-7,38)$ \\
& Angin & \\
4 & Hembusan Angin & $3,3-5,5(7,38-12,3)$ \\
& pelan & \\
5 & Hembusan Angin & $5,5-8(12,3-17,9)$ \\
& Sedang & $8-10,8(17,9-24,16)$ \\
6 & Sejuk & $10,8-13,9(24,16-31,09)$ \\
7 & Hembusan Angin & \\
& Kuat & $13,9-17,2(31,09-38,48)$ \\
8 & Mendekati & $17,2-20,7(38,48-46,3)$ \\
& Kencang & $20,7-24,5(46,3-54,8)$ \\
9 & Kencang & $24,5-28,4(54,8-63,53)$ \\
10 & Kencang Sekali & $28,4-32,6(63,53-72,92)$ \\
11 & Badai & $32,6<(72,92<)$ \\
12 & Badai Dasyat & Badai Topan \\
\hline \hline
\end{tabular}

angin kencang sekali. Manusia masih bisa bertahan menahan angin dengan berjongkok/merunduk hingga kecepatan $60 \mathrm{mph}$ atau kecepatan angin badai. Ketika berpegang pada tali atau menancapkan kapak es dapat bertahan maksimal $80 \mathrm{mph}$ (angin badai topan), selebihnya akan terhempas [7].

Kriteria pengelompokan kecepatan angina mulai yang paling lambat hingga paling kencang ditunjukkan pada Tabel 1 [8]. Dari perhitungan angka Beaufort 10 berpotensi menghempaskan manusia.

Percobaan terowongan angin di Universitas Maryland memberikan nilai $50 \mathrm{mph}$ atau lebih dapat menggerakkan manusia dengan mudah. Pada nilai $40 \mathrm{mph}$ cukup sulit untuk menggerakkan.

\section{Pemodelan DAN VAliDAsi}

\section{A. Pemodelan dan Running}

Pemodelan dengan menggunakan data awal yang telah didapatkan dari PT. Dirgantara Indonesia dan Markas Armada Laut Timur.

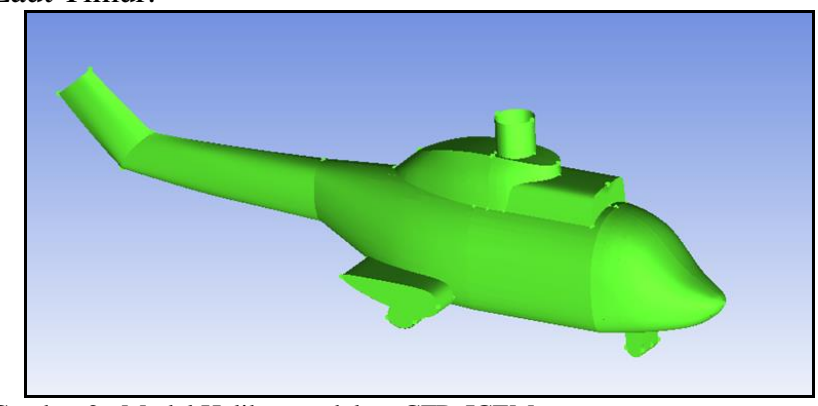

Gambar 2. Model Helikopter dalam CFD-ICEM

Pemodelan melewati beberapa proses tahapan. Proses tersebut diantarannya: 1. Pembuatan model 2D dalam Maxsurf (tampak depan, tampak samping, dan tampak atas). 2. Pembuatan 3D pada Maxsurf 3. Pemindahan model dari 
Maxsurf ke Ansys ICEM. 4. Pembutan kotak pembatas domain dan deck. Hasil pemodelan dapat dilihat pada Gambar 2.

Meshing adalah pembagian sebuah benda menjadi beberapa bagian. Dalam Metode Elemen Hingga ini disebut dengan diskrititasi. Meshing dibuat dengan bantuan ICEM CFD. Caranya adalah dengan membagi geometri model ke dalam elemen-elemen kecil yang disebut cell. Gabungan dari cell-cell tersebut membentuk satu kesatuan yang disebut mesh atau grid karena gabungan dari elemen-elemen tersebut membentuk seperti jala [9].

Model Analisis yang dilaksanakan adalah Stady State. Stady state adalah kondisi dimana model diam dan udara mengalir dari baling-baling (inlet) diteruskan hingga outlet.

Domain adalah kondisi/pengkondisian ruang aliran fluida, pengkondisian di dalam batas inlet-outlet dan di luar model. Domain menggunakan udara pada suhu lingkungan sebesar $25^{\circ} \mathrm{C}$. Pilihan model dengan menggunakan turbulent k-epsilon. Pada tekanan dikondisikan sesuai tekanan ruang yaitu sebesar 1 atm. Model turbulensi k-epsilon merupakan model semi empiris yang dikembangkan oleh Launder dan Spalding [10]. Model k-epsilon merupakan model dua dimensi yang cukup lengkap dengan dua persamaan yang memungkinkan kecepatan turbulen dan skala panjang ditentukan secara independen. Kestabilan, ekonomis (dari sisi komputasi) dan akurasi yang memadai merupakan keunggulan model k-epsilon dalam simulasi aliran fluuida dan perpindahan panas [11].

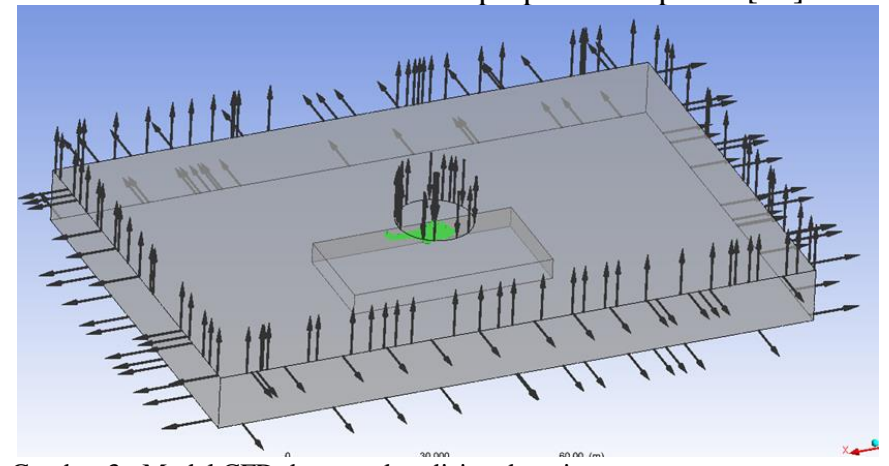

Gambar 3. Model CFD dan pengkondisian domain

Inlet adalah input / lokasi masuknya fluida pada model. Inlet yang dipergunakan berbentuk lingkaran menggantikan posisi baling-baling helikopter. Inlet berada di atas dari model helikopter. Inlet yang diberikan berupa nilai kecepatan disesuai dengan perhitungan 1 sebesar 13,55673 m/s.

Deck dan Helikopter dideskripsikan sebagai Wall. Wall memberikan arti bahwa fluida dapat tertahan/tidak dapat tertembus oleh model.

Outlet adalah kondisi batas penentuan keluarnya fluida. Penempatan outlet pada model adalah disemua sisi samping dan bagian atas (di luar lingkaran inlet) model. Pengkondisian domain, inlet dan outlet ditampilkan dalam Gambar 3.

Running adalah proses perhitungan analisa model aliran fluida pada CFX-Solver Manager.

\section{B. Konvergensi}

Konvergensi adalah pengaturan persamaan solver control untuk meminimalisir error pada hasil simulasi. Proses perhitungan atau disebut sebagai iterasi pada tahap flow solver
[11]. Nilai konvergensi ditentukan pada nilai $10^{-5}$ [12]. Nilai $10^{-5}$ dipergunakan untuk menguji konvergensi pada model yang menggunakan satu jenis fluida.

\section{Grid Independence}

Menurut [9] Grid Independence mencapai posisi optimum apabila selisih perbedaan nilai hambatan antara suatu jumlah elemen dengan elemen sebelumnya kurang dari $2 \%$. Berikut tabel Grid Independence yang telah diperoleh dari penelitian ini.

Tabel 2.

Tabel Grid Independence

\begin{tabular}{|c|c|c|c|c|c|c|}
\hline Percobaan ke & 1 & 2 & 3 & 4 & 5 & 6 \\
\hline Jumlah Element & $\begin{array}{l}4502 \\
2\end{array}$ & $\begin{array}{l}11322 \\
2\end{array}$ & $\begin{array}{l}24711 \\
8\end{array}$ & $\begin{array}{l}50048 \\
7\end{array}$ & $\begin{array}{l}9520 \\
48\end{array}$ & $\begin{array}{l}24454 \\
19\end{array}$ \\
\hline $\begin{array}{l}\text { Nilai Max } \\
\text { Tekanan pada } \\
\text { Deck }(\mathrm{Pa})\end{array}$ & $\begin{array}{l}423,2 \\
2\end{array}$ & $\begin{array}{l}342,9 \\
9\end{array}$ & $\begin{array}{l}312,0 \\
7\end{array}$ & $\begin{array}{l}251,7 \\
6\end{array}$ & $\begin{array}{l}231,9 \\
8\end{array}$ & $\begin{array}{l}228,5 \\
5\end{array}$ \\
\hline$\Delta(\%)$ & & $\begin{array}{l}18,96 \\
\%\end{array}$ & $\begin{array}{l}9,02 \\
\%\end{array}$ & $\begin{array}{l}19,33 \\
\%\end{array}$ & $\begin{array}{l}7,86 \\
\%\end{array}$ & $\begin{array}{l}1,48 \\
\%\end{array}$ \\
\hline
\end{tabular}

Dari Tabel 2 penggunaan jumlah elemen yang relevan terjadi pada percobaan ke-5. Jumlah elemen yang digunakan sebanyak 952.048. Nilai Maksimal tekanan yang diperoleh $231,981 \mathrm{~Pa}$.

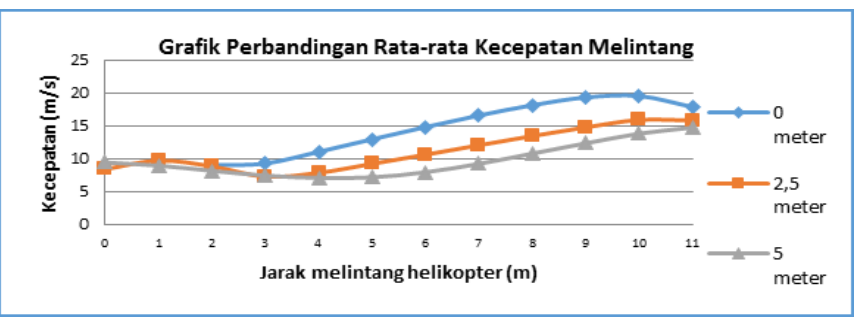

Gambar 4. Grafik Perbandingan Rata-rata Kecepatan Melintang

\section{PEMBAHASAN DAN HASIL}

\section{A. Hasil Perhitungan Kecepatan}

Gambar 4 menggambarkan hubungan kecepatan rata-rata pada helideck dengan jarak melintang. Titik $0 \mathrm{~m}$ menunjukkan pusat baling-baling helikopter, titik $11 \mathrm{~m}$ menunjukkan tepi helideck. Garis teratas adalah garis $0 \mathrm{~m}$, artinya kecepatan rata-rata angin tertinggi dihasilkan oleh helikopter dengan ketinggian $0 \mathrm{~m}$, kecuali di titik $0 \mathrm{~m}$ dan $3 \mathrm{~m}$. Garis terbawah adalah garis $5 \mathrm{~m}$, artinya kecepatan rata-rata angin terendah dihasilkan oleh helikopter dengan ketinggian $5 \mathrm{~m}$. Garis 2,5 m berada di tengah garis grafik, artinya kecepatan rata-rata angin yang dihasilkan oleh helikopter dengan ketinggian 2,5 $\mathrm{m}$ di antara keduanya, kecuali di titik $0 \mathrm{~m}$ dan $3 \mathrm{~m}$.

Pada ketinggian helikopter $0 \mathrm{~m}$ kecepatan tertinggi sebesar $19,614 \mathrm{~m} / \mathrm{s}$ pada titik $10 \mathrm{~m}$, kecepatan terrendah sebesar 9,074 $\mathrm{m} / \mathrm{s}$ pada titik $2 \mathrm{~m}$. Pada ketinggian helikopter 2,5 m kecepatan tertinggi sebesar $15,967 \mathrm{~m} / \mathrm{s}$ pada titik $10 \mathrm{~m}$, kecepatan terrendah sebesar 7,328 m/s pada titik $3 \mathrm{~m}$. Pada garis $1,7 \mathrm{~m}$ kecepatan tertinggi sebesar $14,796 \mathrm{~m} / \mathrm{s}$ pada titik $11 \mathrm{~m}$, kecepatan terrendah sebesar $7,142 \mathrm{~m} / \mathrm{s}$ pada titik $4 \mathrm{~m}$. Secara umum, kecepatan rata-rata angin tertinggi dihasilkan oleh 
helikopter pada ketinggian $0 \mathrm{~m}$ di titik $10 \mathrm{~m}$ yaitu sebesar $19,614 \mathrm{~m} / \mathrm{s}$. Kecepatan angin terendah dihasilkan oleh helikopter pada ketinggian $0 \mathrm{~m}$ di titik $4 \mathrm{~m}$ yaitu sebesar 7,142 $\mathrm{m} / \mathrm{s}$.

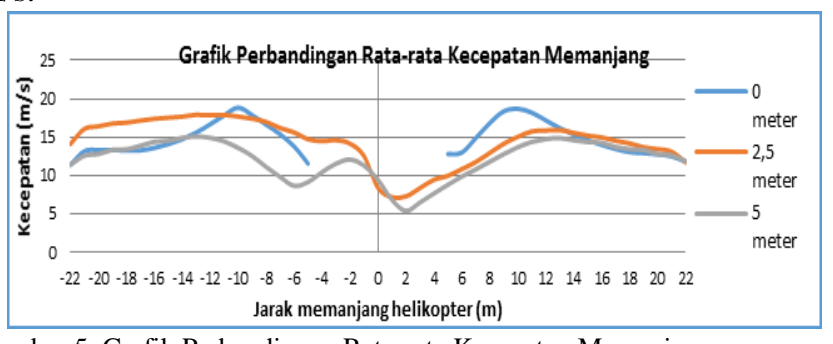

Gambar 5. Grafik Perbandingan Rata-rata Kecepatan Memanjang

Gambar 5 menggambarkan hubungan kecepatan rata-rata pada helideck dengan jarak memanjang. Titik $0 \quad \mathrm{~m}$ menunjukkan pusat baling-baling helikopter, titik $-22 \mathrm{~m}$ dan $22 \mathrm{~m}$ menunjukkan tepi helideck. Garis 2,5 m konsisten di atas garis $5 \mathrm{~m}$, artinya kecepatan rata-rata helikopter dengan ketinggian 2,5 $\mathrm{m}$ cenderung lebih tinggi dibanding dengan helikopter dengan ketinggian $5 \mathrm{~m}$, kecuali di titik $-22 \mathrm{~m}$ dan 0 $\mathrm{m}$. Garis $0 \mathrm{~m}$ bergerak tidak konsisten, di titik -10 dan 5-13 berada di atas kemudian yang lainnya kadang mendekati garis $5 \mathrm{~m}$ kadang mendekati garis $2,5 \mathrm{~m}$, dan terkadang berada terbawah, artinya kecepatan rata-rata angin yang ditimbulkan oleh helikopter ketinggian $0 \mathrm{~m}$ memiliki perubahan nilai yang sangat berbeda dengan ketinggian yang lain.

Pada ketinggian helikopter $0 \mathrm{~m}$ kecepatan tertinggi sebesar $18,855 \mathrm{~m} / \mathrm{s}$ pada titik $-10 \mathrm{~m}$, kecepatan terrendah sebesar $11,418 \mathrm{~m} / \mathrm{s}$ pada titik $-22 \mathrm{~m}$. Pada ketinggian helikopter $2,5 \mathrm{~m}$ kecepatan tertinggi sebesar $17,918 \mathrm{~m} / \mathrm{s}$ pada titik $-13 \mathrm{~m}$, kecepatan terrendah sebesar 7,236 m/s pada titik $1 \mathrm{~m}$. Pada ketinggian helikopter $5 \mathrm{~m}$ kecepatan tertinggi sebesar 15,114 $\mathrm{m} / \mathrm{s}$ pada titik $-13 \mathrm{~m}$, kecepatan terrendah sebesar $5,446 \mathrm{~m} / \mathrm{s}$ pada titik $2 \mathrm{~m}$. Secara umum, kecepatan rata-rata angin tertinggi dihasilkan oleh helikopter pada ketinggian $0 \mathrm{~m}$ di titik $-10 \mathrm{~m}$ yaitu sebesar $18,855 \mathrm{~m} / \mathrm{s}$. Kecepatan angin terendah dihasilkan oleh helikopter pada ketinggian $0 \mathrm{~m}$ di titik $2 \mathrm{~m}$ yaitu sebesar 5,446 m/s.

\section{B. Keamanan Kru}

Kecepatan angin berbahaya pada kriteria kecepatan angin kencang bernilai $20,7-24,5 \mathrm{~m} / \mathrm{s}$. Atau secara kasar nilai yang di berikan bernilai $21,5 \mathrm{~m} / \mathrm{s}$. Batas ambang tersebut hanyalah nilai perkiraan, karena pada kondisi nyata sangat dipengaruhi berat badan, kondisi berdiri orang, alas kaki dan lantai yang dipijak.

Secara memanjang, kecepatan rata-rata angin tertinggi dihasilkan oleh helikopter pada ketinggian $0 \mathrm{~m}$ di titik $-10 \mathrm{~m}$ yaitu sebesar 18,855 m/s. Secara melintang, kecepatan ratarata angin tertinggi dihasilkan oleh helikopter pada ketinggian $0 \mathrm{~m}$ di titik $10 \mathrm{~m}$ yaitu sebesar 19,614 m/s. Ditinjau dari tabel Beaufort penghitungan melintang dan memanjang kecepatan memasuki nilai Beaufort 9 yaitu kriteria angin kencang .

Kriteria kecepatan aman bagi manusia adalah Beaufort 10 yaitu kriteria angin kencang. Ditinjau secara memanjang dan melintang kecepatan rata-rata angin yang dihasilkan oleh pendaratan helikopter tidak ada yang memasuki angka Beaufort 10. Angin yang dihasilkan antara Beaufort 4 hingga Beaufort 9 atau kriteria Hembusan Angin Pelan sampai Angin Kencang. Artinya angin yang ditimbulkan karena pendaratan helikopter pada Studi ini tidak berbahaya bagi orang yang bekerja pada daerah helideck. Namun perlu diingat bahwa angka Beaufort 9 adalah kriteria yang akan menghempaskan manusia diam, tidak termasuk orang bergerak. Saat manusia bergerak atau berjalan santai bisa jadi angka Beaufort 9 berbahaya dan sudah dapat menghempaskannya.

Biarpun angin yang dihasilan dari pendaratan helikopter tidak mencapai Beaufort 10, namun tidak disarankan selain tim pendaratan berada dilokasi helideck. Karena dalam kondisi tidak siap atau kondisi bergerak, angka Beaufort 9 memilki potensi dapat menghempaskan manusia.

\section{KESIMPULAN}

CFD mampu menyelesaikan perhitungan numerik dan algoritma pada pergerakan fluida. Dengan menggunakan software CFD pada komputer mampu mensimulasikan interaksi dan gerakan fluida.

Dari perhitungan CFD dapat disimpulkan semakin rendah helikopter semakin cepat angin yang dihasilkan. Berikut rincian kecepatan angin yang dihasilkan: 1. Pada ketinggian Helikopter 0 meter menghasilkan kecepatan angin sebesar 9,073-19,614 $\mathrm{m} / \mathrm{s}$ pada perhitungan melintang dan sebesar $11,418-18,855 \mathrm{~m} / \mathrm{s}$ pada perhitungan memanjang. 2. Pada ketinggian Helikopter 2,5 meter menghasilkan kecepatan angin sebesar 7,327-15,967 $\mathrm{m} / \mathrm{s}$ pada perhitungan melintang dan sebesar 7,236-17,918 m/s pada perhitungan memanjang. 3 . Pada ketinggian Helikopter 5 meter menghasilkan kecepatan angin sebesar 7,141-14,795 m/s pada perhitungan melintang dan sebesar 5,446-15,114 m/s pada perhitungan memanjang.

Radius angin yang di hasilkan dari pendaratan helikopter pada semua ketinggian mencapai tepi helideck. Di semua variabel ketinggian, pada tepi deck jarak radius $11 \mathrm{~m}$ melintang dan jarak radius $22 \mathrm{~m}$ memanjang keduanya memiliki nilai kecepatan angin. Artinya hingga ujung tepi deck ada angin yang berhembus.

Kriteria ambang kecepatan aman bagi manusia Beaufort 10. Pada penelitian ini kecepatan yang ditimbulkan karena pendaratan helikopter pada kriteria Beaufort 4 hingga Beaufort 9. Dari kriteria angin dan hasil penelitian dapat disimpulkan hembusan angin yang dihasilkan dari pendaratan helikopter dapat dikatakan aman bagi kru yang bekerja di helideck. Meski demikian tapi tidak disarankan bagi orang awam (tidak terlatih) berada di helideck saat terjadi pendaratan helikopter, karena pada kondisi tertentu kriteria Beaufort 9 memungkinkan dapat menghempaskan seseorang.

\section{UCAPAN TERIMA KASIH}

Penulis MZFR mengucapkan terima kasih kepada PT. Dirgantara Indonesia Khususnya Bapak Taufik dan Armada Laut Timur khususnya Letda Raditia karena telah mengizinkan 
dan membantu dalam pencarian data. Penulis juga diperkenankan menyampaikan ucapan terima kasih kepada Luqman, Bang Taslim, Dr. Barlaw, Susmita, S Irawan, dan Mas Sutiyo yang telah membantu penulisan ini. Terakhir penulis menyampaikan terimakasih kepada Ibu Sri Rejeki Wahyu Pribadi, M.T., Bapak Aries Sulisetyono, Ph.D., dan Bapak Dr. I Ketut Suastika yang telah berkenan mereview penulisan ini.

\section{DAFTAR PUSTAKA}

[1] K. P. P. RI, "Undang-undang Republik Indonesia nomor 1 tahun 2009 tentang Penerbangan," hubud.dephub.go.id, 2016.

[2] B. Bandung, Peraturan Bupati Bandung Nomor 56 Tahun 2010, Tentang Pedoman Pembangunan Heliport di Kabupaten Bandung. 2010.

[3] J. D. Anderson, Computation Fluid Dynamics, The Basics with Applications, International Editions. Singapore: McGraw-Hill, 1995.

[4] M. Kaimuddin, "Analisis Aliran Fluida Diatas Geladak Kapal Saat Pendaratan Helikopter," Institut Teknologi Sepuluh Nopember, 2003.

[5] L. Lebrag, "Tentang Computational Fluid Dynamics (CFD),” 2014.
[Online]. Available: http://fisikaveritas.blogspot.co.id/2014/03/tentang-computationalfluid-dynamics-cfd.html.

[6] J. G. Leishman, Principle of Heliopter Aerodynamics. In: W. Shyy \& M. J. Rycroft, eds. Cambridge: Cambridge University Press, 2008.

[7] Muphrid, "What does the wind speed have to be to blow away a person?," 2012. [Online]. Available: https://physics.stackexchange.com/questions/41934/what-does-thewind-speed-have-to-be-to-blow-away-a-perso.

[8] M. N. Aji, D. R. \& Cahyadi, "Analisa Karakteristik Kecepatan Angin dan Tinggi Gelombang Menggunakan Data Satelit Almetri (Studi Kasus: Laut Jawa)," GEOID, vol. 11, pp. 75-78, 2015.

[9] G. M. Ahadyanti, "Modifikasi Bentuk Lambung pada Shallow Draft Bulk Carrier untuk Menurunkan Konsumsi Bahan Bakar," Institut Teknologi Sepuluh Nopember, 2014.

[10] F. Tuakia, Dasar-dasar Menggunakan CFD Fluent. Bandung: Informatika, 2008.

[11] A. Gibson, "Analisis Cfd Hambatan Lambung Kapal Trimaran Asimetris Flat Side Inside Dengan Variasi Jarak Antar Lambung Secara Membujur," Institut Teknologi Sepuluh Nopember, 2016.

[12] A. Y. Setiawan, "Modifikasi Bentuk Buritan pada Shallow Draft Bulk Carrier untuk Meningkatkan Efisiensi Sistem Propulsi," Institut Teknologi Sepuluh Nopember, 2014. 